\title{
Does Chief Executive Officer (CEO) Leadership Style Matter? An Empirical Analysis of the Relationship among CEO Leadership Style, Job Satisfaction and Profitability in Nepali Financial Institutions
}

\author{
Raju Uprety* \\ Kathmandu University School of Management, Lalitpur, Nepal
}

\begin{abstract}
The impact of Chief Executive Officer (CEO) leadership style on the profitability of an organization has been a major concern of much academic research work in the past. However, there seems to be no consensus on this issue. It is generally believed that leaders influence organizational performance through those they lead. Therefore, employee job satisfaction is hypothesized to have a mediating effect on the relationship between the CEO leadership style and the profitability of an organization. This study, conducted among 136 employees of 17 finance companies in Nepal during December 2013, found a very weak relationship between the CEO leadership style and the profitability of an organization. The study also refuted the mediating effect of job satisfaction on the relationship between the CEO leadership style and the profitability of an organization. The findings support the contextualists view on the leadership-performance debate. The probable reasons and implications of the findings are discussed.
\end{abstract}

Keywords: CEO leadership style, job satisfaction, profitability, Nepali financial institutions

\section{Introduction}

Does the leadership style of a top leader make any difference in the performance of an organization? This has been a major concern of much academic research work in the past. Some studies (e.g. Barley, 1991; Collins, 2001; Day \& Lord, 1988; Joyce, Nohria, \& Roberson, 2003; Thomas, 1988), using various methodologies, have concluded that changes in the top leadership is followed by changes in the organizational performance. Day and Lord (1988) and Thomas (1988) estimated the effect of executive leaders to be as high as $20 \%$ to $45 \%$, depending upon the measure of organizational performance. Some other scholars (e.g., Lieberson \& O'Conner, 1972;Preffer, 1977) argue that the effects of leadership are of less importance when compared to historical, organizational, and environment forces. In this regard, Meindl and Ehrlish (1987) suggest that attributing organizational outcomes to individual leaders is a romantic oversimplification.

The effect of leadership style on an organization is manifested in terms of organizational performance. Although the term organizational performance encompasses many other variables and constructs, it can be argued that in the case of profit making business organizations, the term is truly reflected in the hard measure of profitability of the organization. For instance, Joyce et al. (2003)

* Author Email: rajuuprety@gmail.com 
found that Chief Executive Officers (CEOs) account for 14\% of the variance in a firm's financial result. Some studies (e.g., Angle, Nagarajan, Sonnenfeld, \& Srinivasan, 2006; Waldman, Javidan, \& Varella, 2004) found a direct relationship between the CEO leadership style and the objective measures of the financial performance, but other studies (e.g., Tosi, Misangyi, Fanelli, Waldman, \& Yammarino, 2004;Zhu, Chew, \& Spangler, 2005) refuted any such relationship. This indicates that there is no consensus in this area of academic discourse.

Hogan and Kaiser (2005) have stated that leaders do not achieve results themselves. They influence organizational outcomes through their followers. Generally, an employee satisfied with his or her job condition is expected to exert more effort towards higher profitability. The relationship between leadership style and job satisfaction is established by prior studies (e.g., Rad \& Yarmohammadian, 2006). The job satisfaction of an employee is further believed to have influence on the profitability of the organization. Moreover, the profitability of any profit making organization is attributed to many factors. Some prior studies conducted in the western countries have established a relationship between a CEO's leadership style and the profitability of an organization. However, the findings of those studies might not accurately reflect the context of Nepal because of the differences in national cultures. Moreover, no study was found that examined the effect of 'employee job satisfaction' in regard to the relationship between the CEO leadership style and the profitability of an organization in a Nepali context. Thus, this paper examines the nature of relationship among CEO leadership style, followers' job satisfaction, and organizational profitability in Nepali financial institutions.

This paper is presently more relevant to the context of the Nepali banking industry, as there is currently a large gap between the compensation of a CEO and other staff members. In response to wide spread grievances regarding extravagant salary and compensation of CEO in Nepali financial institutions, Nepal Rastra Bank (NRB), the regulatory authority of the banking industry, issued guidelines on 26 October 2010 and 5 September 2011 in an effort to put a cap on the CEO's salary and compensation plans. Such guidelines, though already enforced by NRB, have received sharp criticisms, especially from the banking community. Critics of the guidelines justify the CEO's salary by the institution's profitability and the CEO's contribution to that profitability. One of the major contributions of the CEO is his or her leadership to the institution.

The finding of this study contributes to the ongoing discourse on the relationship between CEO leadership style and profitability. Probably the most important contribution of this study will come from the choice of its population. Strong arguments are being made both for and against putting a limit on the CEO's salaries. However, no study has been found that has made an attempt to quantify the contribution of the CEO leadership style on the profitability of the organization in the context of Nepali banking sector.

\section{Theoretical Background}

The findings of the existing literature on the relationship between the CEO leadership style and the objective measures of the financial performance are mixed. Angle et al. (2006), and Waldman et al. (2004) found a direct relationship between the CEO leadership style and the objective measures of the financial performance. However Tosi et al. (2004) and Zhu et al. (2005) could not find any relationship between these two variables.

Most studies trying to establish a relationship between leadership style and organizational performance have considered charismatic leadership as one of the major dimensions of leadership

Journal of Business and Management Research, July 2016, Vol. 1, No. 2 
style. For example, Waldman, Ramirez, House, and Puranam (2001) have considered transactional and charismatic as major dimensions of leadership. They have used charismatic in lieu of transformational leadership style. Angle et al. (2006) have considered only the charismatic leadership style in relation to organizational performance. The existing literature seems to argue that the charismatic leadership style, out of all available leadership styles in the literature, would affect performance of an organization the most. Many studies on the relationship between leadership style and organizational performance have taken environment uncertainty as a moderating variable. Angle et al. (2006) and Waldman et al. (2001) established that the charismatic leadership style makes the contribution on organizational performance, and profitability in particular, during the time of environment uncertainty. In this case, environment uncertainty acted as a moderating variable in the relationship between leadership style and profitability of the organization.

Rad and Yarmohammadian (2006) found a significant correlation between use of leadership behavior and employee job satisfaction. This finding was further supported by Saleem (2015). In a study conducted among school teachers, Bogler (2001) found that principal's transformational leadership affected teacher's satisfaction both directly and indirectly. Voon, Lo, Ngui, and Ayob (2011) concluded that both transactional and transformational leadership were found to have direct relationship with employees' job satisfaction.

\section{Conceptual Framework}

The fundamental conceptual premise of this study is that the leadership style of CEO affects profitability of an organization. This effect on the profitability of an organization is brought about by the leader through their followers (Hogan \& Kaiser, 2005). The literature suggests that when followers are satisfied, they are willing to comply with the leader's requests for the maximum possible effort in achieving the organizational goals and targets. Against this backdrop, it is assumed that, normally, when employees comply with the leader's request for the maximum possible effort, organizational profitability increases, other things remaining the same. Thus, employee job satisfaction is conceptualized as a mediating variable in the relationship between the CEO leadership style and the profitability of an organization.

Profitability of an organization is indicated by the financial performance of the organization. Financial performance is measured by return on asset (ROA), return on equity (ROE), net profit margin (NPM), and growth in deposit (GD). ROA and ROE as measures of financial performance were used by Angle et al. (2006). NPM as a measure of financial performance was used by Waldman et al. (2001). GD as a unique measure of financial institutions is added in this study. GD is not a direct measure of the profitability but it increases the lending capability of the financial institutions. Interest rates charged by banks on loan compare to rates they pay on deposit are always higher. Thus, it is assumed that GD contributes to the profitability of the organization. Earlier studies probably ignored GD as a financial measure because those studies were not specific to the financial institutions. All these measures are on percentage, not on an absolute value.

Size of the organization was measured in terms of total asset. Tenure of the CEO and performance prior to the review period was treated as control variables. Virany, Tushman, and Romanelli (1992); and Waldman et al. (2001) argue that organization size, CEO tenure, and prior performance should be controlled in research seeking to relate the CEO characteristics with the organizational performance.

The charismatic dimension of leadership was predominantly used in prior studies to assess the relationship between the CEO leadership style and the financial measures of an organizational 
profitability; however, transactional and transformational dimensions are used in this paper as the later has gained much research attention in the recent literature. In addition, measurement instrument are well developed for transformational dimension when compared to that of charismatic dimension.

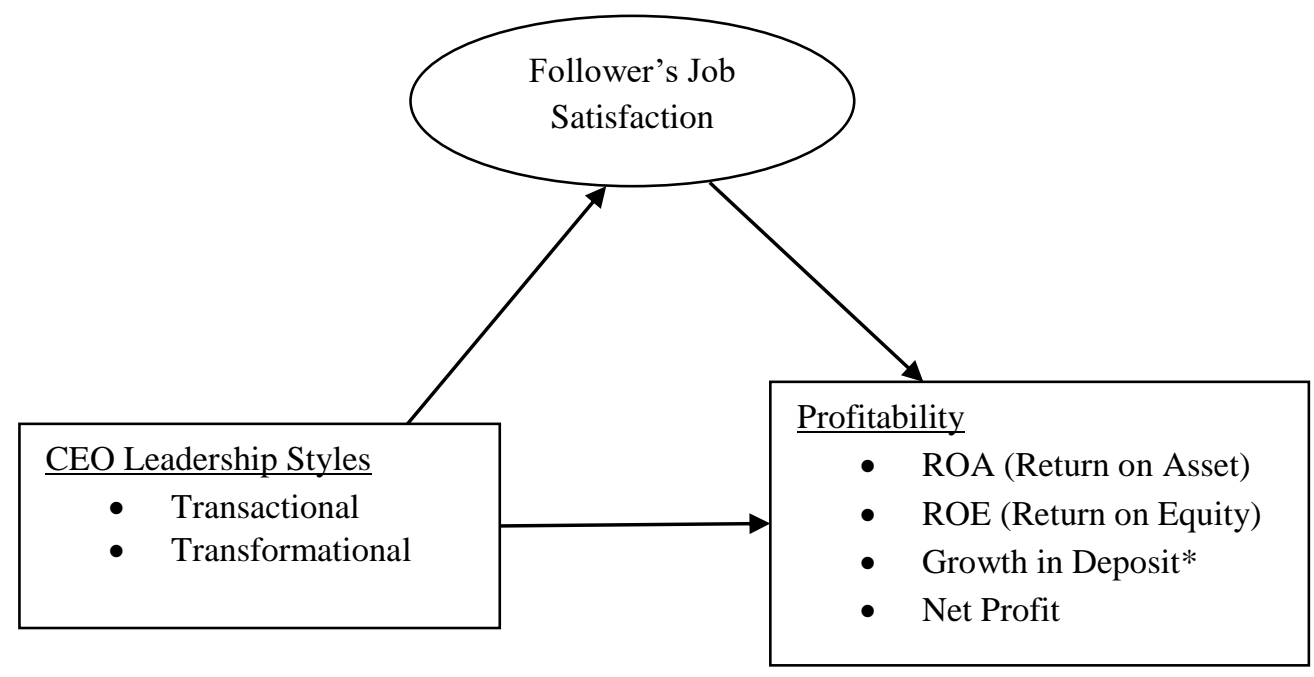

\section{Control Variables}

- $\quad$ Size of the Organization

- $\quad$ CEO Tenure

- Past Performance on Financial Measures

* Growth in Deposit, though not a direct measure of profitability, is considered in this study. Please see discussion under conceptual framework.

Figure 1. Conceptual framework.

Also, charismatic leadership style is mostly associated with environment uncertainty as a moderating variable but the conceptual model that is proposed in this paper does not have environment uncertainty as a moderating variable, and most importantly all CEOs from the population of this study might not be charismatic.

Tosi (1982) stated that transactional leaders are those who help to shape strategies and structures, reward subordinates' efforts and commitment, and take action to correct mistakes and deviations from expectations. This approach of leader will induce followers to contribute to the profitability in case of for-profit organizations. Thus, it is proposed that:

H1(a): Transactional leadership on the part of CEOs is positively associated with the organizational profitability. 
Bass (1985) argues that transformational leaders are those who motivate followers by making them more aware of the importance of task outcomes, inducing them to transcend their own self-interest for the sake of the organization or team, and activating their higher order need. This approach of the leader will streamline efforts of the followers towards contribution to the profitability of the organizations in case of for-profit organizations. Thus, it is proposed that:

H1(b): Transformational leadership on the part of CEOs is positively associated with the organizational profitability.

Various scholars (e.g.,Bogler, 2011; Rad \& Yarmohammandion, 2006; Saleem, 2015; Voon, Lo, Ngui \& Ayob, 2011) reported significant relationship of transactional and transformation leadership style with employee job satisfaction. In their comprehensive review of relationship between leadership and job satisfaction, Belias and Koustelios (2014) concluded that leadership style is an important antecedent of job satisfaction. Thus, it is proposed that:

H2(a): Transactional leadership on the part of CEOs is positively associated with the employee's job satisfaction.

H2(b): Transformational leadership on the part of CEOs is positively associated with the employee's job satisfaction.

Hogan and Kaiser (2005) concluded that the effect on the profitability of an organization is brought about by the leader through their followers. Existing literature also suggests that when followers are satisfied, they are willing to comply with the leader's request for the maximum possible effort in achieving the organizational goals and targets. Thus, it is proposed that

H3: Job satisfaction is positively associated with organizational profitability.

Though there exist no prior studies that suggest the mediating effect of job satisfaction on the relationship between the leadership style and the profitability of the organization, mediating effect of job satisfaction is hypothesized based on the findings of Hogan and Kaiser (2005). They argue that leaders affect organizational performance through followers. An organization performs well only when its employees perform well. It also means, satisfied employees perform better than unsatisfied counterparts. Rad and Yarmohammadian (2006) andBelias and Koustelios (2014) claim a relationship between leader's leadership style and employee job satisfaction. Thus, it is proposed that:

H4: Employee job satisfaction mediates the relationship between the leadership style and the profitability of the organization.

\section{Methods}

Population for this research comprises financial institutions licensed as class C by NRB and having minimum one office within Kathmandu, Lalitpur or Bhaktapur districts. The total number of such financial institution was 58 excluding Samjhana Finance Co. Ltd. which during the time of this study was in the process of liquidation. Six institutions that had no presence either in Kathmandu, Bhaktapur or Lalitpur district were excluded from the population because of difficulty in contacting those institutions and administering the questionnaires. This makes the population of 52 institutions. Similarly, the total employees working in offices of Kathmandu, Lalitpur orBhaktapur were estimated to be 1409 based on the telephone enquiry with the concerned officials of those institutions. These 52 
institutions were divided into four strata based on average Net Profit Margin (NPM) from the period Asar 31, 2069 (corresponding AD date- July 15, 2012) till the period Chaitra 31, 2069 (corresponding AD date- April 13, 2013). The top 30 percent performers were grouped in a stratum-1, whereas the lowest 30 percent performers were grouped in stratum- 4. Remaining $40 \%$ were further divided into two halves. Top half as middle upper performer in stratum-2 and lower half as middle lower in stratum-3. This is to ensure the variability in measures of the financial performance by ensuring participation from all strata.

Initially all 52 institutions were approached during December 2013 through phone calls for participation. Some institutions did not show an interest in participating, whereas others were reluctant to respond after knowing the purpose of the research. Some institutions dropped because the then CEO's joining date was after the determined cut-off date. Total of 469 questionnaires were distributed to 22 those institutions that accepted to receive questionnaire. Three institutions did not return even a single questionnaire. There were total 154 usable questionnaires from 19 institutions after dropping questionnaires with incomplete mandatory section, and with extreme and neutral response in all Likert items. This made the response rate of $32.83 \%$. Two institutions further dropped because it was discovered later on that CEO's joining date of those two institutions were after the determined cut-off date. Thus, 136 usable questionnaires from 17 institutions were available for final analysis. Out of the total 136 respondents, $46 \%$ were male, $43 \%$ were female and $11 \%$ choose not to disclose their gender. Similarly, 9\% were of manger level, $12 \%$ were of officer level, $61 \%$ were of supervisor and assistant level, and $18 \%$ chose not to disclose their level. It was not mandatory to disclose their gender and level in the organizational hierarchy.

Transactional leadership dimension was assessed by using five items from Multifactor Leadership Questionnaire (MLQ) as done by Waldman et al. (2004). Cronbach alpha for these 5 items as reported by Waldman et al. was .81. Five items used to assess transactional leadership dimension are given in the Appendix. Items 2, 3 and 5 represent contingent reward behaviour; items 1 and 4 represent active management by exception. The relation of passive management by exception to performance is not clearly established in the literature (Waldman et al., 2001). So, the item related to passive management by exception was not included. Transformational leadership dimension was also assessed by using five items from MLQ. These five items are given in the Appendix. Reliability score of these five items was not known while designing this study. However, the reliability score was checked with the responses of this study. Moreover, the five items used in this research was drawn from a widely used and accepted scale to measure leadership type in academia. Similar practice was done by Waldman et al. (2001) to assess charismatic dimension of leadership. Reason for proposing to use a reduced version of MLQ is to ensure high response rate. Transformational leadership has four dimensions namelyidealized influence, individualized consideration, inspirational motivation, and intellectual stimulation. Out of five items used to measure the transformational leadership, items 1 and 2 measured idealized influence; item 3 measured inspirational motivation; item 4 measured intellectual stimulation; and item 5 measured individualized considerations.

Job satisfaction was measured by five items originally developed by Quinn and Shepard (1974) and subsequently modified by Pond and Geyer (1991) and Rice, Gentile, and McFarlin (1991). This measure originally had six items. However, only five items out of original six items were used by Birnbaum and Somers (1993), McFarlin and Rice (1992), Mossholder, Bennett, and Martin (1998), and Williams, Gavin, and Williams (1996). The coefficient alphas of those five items were reported in range of .81 to .89 (as cited in Fields, 2002). The five items used to measure job satisfaction are given in the Appendix. 
Instruments used to measure the leadership style and job satisfaction consisted of Likert scale items. Responses to leadership style item were collected from CEO's subordinates and responses to job satisfaction questionnaire were self-reported by the same respondents who responded on the CEO leadership style.

Measures of profitability like Return on Asset (ROA), Return on Equity (ROE), Net Profit Margin (NPM), and Deposit Growth (DG) were taken from the website of NRB. Quarterly data were available starting from Poush 30, 2066 BS (corresponding AD date- January 14, 2010) till Asar 31, 2070 BS (corresponding AD date- July15, 2013). This means data were available for 16 periods. In case of the CEO whose joining date was prior to January 14, 2011, the base date for assessing financial performance was considered to be January 14, 2011. Likewise, the average of ROA, ROE, NPM, and DG of immediate four periods prior to January 14, 2011 was considered as base ROA, ROE, NPM, and DG. In case of the CEO whose joining date was after January 14, 2011, the period ending immediately after joining of the CEO was considered as the base date. In such cases, base ROA, ROE, NPM, and DG was calculated based on last four periods from the base date. Base ROA, ROE, NPM, and DG was the measure of past performance. The average of ROA, ROE, NPM, and DG from the period immediately after the base date till Asar 31, 2070 (corresponding date- July 15, 2013) was considered as the financial performance of the organization during the review period. Some figures of ROA, ROE, NPM, and DG during the review period were above or below $100 \%$. Such figures were dropped while calculating the average. It is assumed that such figures were seen due to non-ordinary activities during the review period and thus were not a part of regular business activities. So, such figures were dropped to avoid the resulting average figure being skewed. There was no need to adjust ROA, ROE, NPM, and DG for industry average as all companies were taken from the same industry. Nevertheless, the institutions where the CEO's joining date was after April 12, 2012 were not considered for analysis because it was assumed that it would take some time for the CEO leadership style to reflect on the financial measures of organizational profitability.

\section{Results}

Responses to the items in the questionnaire and data on the measures of financial performance were loaded in SPSS for further analysis. Cronbach alpha of five items measuring transactional leadership was found to be .61, of five items measuring transformational leadership was found to be .71, and for five items measuring job satisfaction was found to be .85 . New composite variables were calculated as an average score of the constructs - transactional leadership, transformational leadership, and job satisfaction. These new variables were named L_Transactional, L_Transformational, and Job_Satisfaction. The mean score for L_Transactional was 2.44, for L_Transformational was 2.47 on a scale of 0 to 4. Likewise, the mean score of Job_Satisfaction was 3.20 on a scale of 1 to 5. The mean scores for L_Transactional, L_Transformational, and Job_Satisfaction were just above the average.

Significance, strength, and direction of relationships among transactional leadership, transformational leadership, various measures of financial profitability, and job satisfaction were assessed through partial correlation analysis. Variables controlled were CEO tenure, total asset, and past performance. Past performance included ROA_base, ROE_base, NPM_base, and DG_base.

Table 1 indicates that three measures of financial profitability NPM, ROE, and ROA were significantly and positively associated with transactional leadership. None of the profitability measures were significantly associated with transformational leadership. Likewise, job satisfaction was 
significantly and positively related to transactional leadership and transformational leadership. Three measures of profitability NPM, ROE, and ROA were significantly and positively associated with job satisfaction, but DG was not associated with job satisfaction. Results from Table 1 indicated limited support for H1(a); full support for $\mathrm{H} 2$ (a), H2(b) and H3; and no support to H1(b).

Table 1

Partial Inter-correlation

\begin{tabular}{|c|c|c|c|c|c|c|c|c|}
\hline & & 1 & 2 & 3 & 4 & 5 & 6 & 7 \\
\hline 1 & L_Transactional & & & & & & & \\
\hline 2 & L_Transformational & $.60 *$ & & & & & & \\
\hline 3 & Job_Satisfaction & $.44^{*}$ & $.37 *$ & & & & & \\
\hline 5 & DG_Avg & .1 & -.06 & .06 & .02 & & & \\
\hline 6 & NPM_Avg & $.19 * *$ & .11 & $.18^{* *}$ & .17 & $.63 *$ & & \\
\hline 7 & ROE_Avg & $.19 * *$ & .04 & $.21 * *$ & .12 & $.75^{*}$ & $.88^{*}$ & \\
\hline 8 & ROA_Avg & $.16^{* *}$ & .04 & $.30 *$ & .11 & $.36^{*}$ & $.83^{*}$ & $.76^{*}$ \\
\hline
\end{tabular}

Note: $* p<.0 .05 ; * * p<0.01$; DG_Avg: Average DG during the review period; NPM_Avg: Average NPM during the review period; ROE_Avg: Average ROE during the review period; ROA_Avg: Averge ROA during the review period

Limited support for H1(a) was further diagnosed using hierarchical regression. Hierarchical regression was conducted to see the effect of two leadership styles- transactional and transformational independentlyafter controlling for the past performance, CEO tenure, and total asset.The effect of transactional and transformational variable on ROA was assessed through hierarchical regression after controlling the past performance, CEO tenure, and total asset. Transactional and transformational variables were found to have no significant effect on ROA. The effect of transactional and transformational variable on ROA remained the same even when only the past ROA (and not other measures of profitability) was controlled.

The effect of transactional and transformational variable on ROE was assessed through hierarchical regression after controlling the past performance, CEO tenure, and total asset. Transactional and transformational variable were found to have no significant effect on ROE. The effect of transactional and transformational variable on ROE remained the same even when only the past ROE (and not other measures of profitability) was controlled.

The effect of transactional and transformational variable on NPM was assessed through hierarchical regression after controlling the past performance, CEO tenure, and total asset. Transactional and transformational variables were found to have no significant effect on NPM. The effect of transactional and transformational variables on NPM remained the same even when only the past NPM (and not other measures of profitability) was controlled.

Effect of transactional and transformational variable on DG was assessed through hierarchical regression after controlling the past performance, CEO tenure, and total asset. Transformational variables were found to have no significant effect on DG. However, transactional leadership style had shown significant effect $(p<.01)$ on DG when only the past DG (and not other measures of profitability) was controlled. 
Table 2

Results of Hierarchical Regression

\begin{tabular}{|c|c|c|c|c|}
\hline \multirow[b]{2}{*}{ Predictors } & \multicolumn{4}{|c|}{ Dependent Variable } \\
\hline & ROA & ROE & NPM & DG \\
\hline \multicolumn{5}{|l|}{$\begin{array}{l}\text { Model } 1 \text { (Control } \\
\text { Variables) }\end{array}$} \\
\hline Total Asset & $.41^{*}$ & $.42 *$ & .05 & $.58^{*}$ \\
\hline CEO Tenure & $.39 *$ & $.21 *$ & .27 & $.30 *$ \\
\hline ROA_Base & $.51^{*}$ & & & \\
\hline ROE_Base & & $.84 *$ & & \\
\hline NPM_Base & & & -.05 & \\
\hline DG_Base & & & & -.03 \\
\hline$R^{2}$ & .35 & .74 & .06 & .37 \\
\hline$F$ & $21.98 *$ & $116.10 *$ & 2.75 & $23.52 *$ \\
\hline \multicolumn{5}{|l|}{$\begin{array}{l}\text { Model } 2 \text { (Test } \\
\text { Variables) }\end{array}$} \\
\hline Total Asset & $.41^{*}$ & $.41 *$ & .04 & $.56^{*}$ \\
\hline CEO Tenure & $.40^{*}$ & $.22 *$ & .26 & $.26 * *$ \\
\hline ROA_Base & $.51^{*}$ & & & \\
\hline ROE_Base & & $.83^{*}$ & & \\
\hline NPM_Base & & & -.05 & \\
\hline DG_Base & & & & -.1 \\
\hline Transactional & .05 & .1 & .12 & $.30 * *$ \\
\hline Transformational & -.06 & -.09 & -.03 & -.11 \\
\hline$R^{2}$ & .35 & .75 & .07 & .42 \\
\hline$F$ & $13.09 *$ & $70.58 *$ & 1.91 & $17.27 *$ \\
\hline
\end{tabular}

The results of hierarchical regression providedlimited support for $\mathrm{H} 1$ (a); full support for $\mathrm{H} 2$ (a), $\mathrm{H} 2$ (b) and $\mathrm{H} 3$; and no support to H1(b).Transactional leadership style had significant positive relationship with DG. This finding was consistent with the finding of partial correlation analysis.

The only significant relationship was found between transactional leadership style and DG. So, the mediating effect of job satisfaction was only tested with this relationship. Applying the procedures as recommended by Baron and Kelly (1986, as cited in Poon, 2004), relationship was established between independent variable (transactional leadership) and dependent variable (DG), between independent variable (transactional leadership) and mediating variable (job satisfaction), and between dependent variable (DG) and mediating variable (job satisfaction) after controlling for independent variable 
(transactional leadership). These tests between dependent, independent, and mediating variables were done in the environment where the past performance on DG was controlled because the relationship between transactional leadership (independent variable) and DG (dependent variable) was found significant under condition when the past performance on DG was controlled. Likewise, the relationship between transactional leadership and DG was found to be significant $(p<.05)$; and between transactional leadership and job satisfaction was also found to be significant $(p<.01)$. After controlling for effect of transactional leadership, the relationship between job satisfaction and DG was found to be non-significant. This result indicated that the relationship between independent, dependent, and mediating variable was not eligible for the test of mediation effect. Thus, it was concluded that the relationship between transactional leadership and DG was not mediated by job satisfaction. This test provided no support to $\mathrm{H} 4$.

\section{Discussion}

The mean scores for job satisfaction, transactional leadership, and transformational leadership were just above average. This indicates that the CEOs of Nepali financial institutions do not exhibit strong leadership behaviour. Leadership as one of the roles of CEOs of Nepali financial institutions has not received much attention yet. None of the profitability measures was associated with transformational leadership, but one of the profitability measures was associated with transactional leadership. Profitability is a hard measure which is conceptually close to transactional leadership instead of transformational leadership. Neither transactional nor transformational leadership style was found to influence ROA, ROE, and NPM measures. However, transactional leadership style was found to have an influence on DG.

The relationship between job satisfaction and DG when controlled for past DG, CEO tenure, total asset, and transactional leadership was not significant. This means highly satisfied employee will not lead to DG. This finding sounds obvious. Just because employees are highly satisfied does not mean they will exert more effort on something that is not their specific responsibility. Moreover, DG is a function of liquidity available in the market, interest rate offered by the institution in its various deposit products, credibility of the institution in the market, and other factors. However, job satisfaction is found to have significant relationship with other measures of profitability like ROA and NPM.

In general, this study found a very weak relation of leadership style with financial measures of profitability of an organization. The findings of this study tend to support contextualists view on leadership-performance debate. Early debate on leadership-performance was dominated by individualist view. Individualist view generally assumes that leaders have a significant and possibly crucial impact on the performance of the organizations they head. Lately, this individualist view has been challenged by contextualists. Contextualists are of view that the direct effect of leaders on the organizational performance is influenced by situational factors (Hall, 1977; Pfeffer \& Salancik, 1978, as cited in Thomas, 1988). Pathbreaking study of Lieberson and O'Conner (1972) seems to be a starting point of contextualists' view which hasbeen further supported by studies of Allen, Panian, and Lotz (1979, conducted among sports organization), of Pfeffer and Salancik (1978, as cited in Thomas,1988, conducted among governmental institutions) and of Samuelson, Galbraith, and McGuire (1985, conducted among industrial organizations).

Finance companies in Nepal do fall under the banking industry which is highly regulated by a powerful regulator. NRB dictates the sector to which finance companies can offer a loan product, and 
also regulates the maximum amount of deposit finance companies can accept from a single institution. $\mathrm{NRB}$ also regulates interest rate by issuing various directives like provisions of base rate, interest rate corridor, etc. Various regulations of NRB provide context within which leadership of finance companies should operate. In the observation of the author, lower end of market of finance companies are being constantly invaded by saving and credit co-operatives; and upper end of the market is being constantly invaded by class B financial institutions called development banks. Saving and credit cooperatives are regulated by Department of Co-operatives. There is a widespread belief in popular press that Department of Co-operatives is a weak regulator in comparison to NRB (Ghimire, 2014) since saving and credit co-operatives need to comply with less stringent rules and regulations than those of finance companies. Finance companies do also have restriction on offering products (e.g., overdraft loan, foreign exchange, letter of credit) and extending the size of deposit and loan when compared with development banks. These contextual factors might have posed serious challenges for the CEO leadership style to have a significant impact on the financial measures of profitability.

Interestingly, out of 17 organizations only four had improved ROA, one had improved ROE, two had improved NPM, and eight had improved DG in the review period in comparison to their respective base period. The review period had witnessed severe liquidity crisis in Nepali banking sector (Spotlight, 2011; eKantipur, January 31,2013; eKantipur, February 25,2013). Severe liquidity crisis and constant invasion of market from both the ends might be a reason for the poor performance of finance companies in the review period vis-a-vis a base period. This poor performance of finance companies during the review period because of economy and market factors may have acted as a strong contextual factor restricting leadership to have any significant relationship with the financial measures of profitability.

At a broader level, findings of this study signal the inherent weaknesses of the great man theory. Great man theory fails to consider a leader's bounds. No one would deny the assertion that certain individuals have a disproportionate influence upon the course of development of the groups to which they belong; however, the evidence indicates that the influence of a single individual is seldom decisive (Freedman et al., 1956, as cited in Lieberson \& O'Conner, 1972). Meindl and Ehrlish (1987) attributed the reason for general expected relationship between leadership and performance of an organization to the concept of romanticization of leadership. They explained that romanticization of leadership states that leadership has assumed a special status; it is no more just another alternative variable that explains organization performance. People do not consider leadership on equal footing with other explanatory variables to organization performance because leadership has achieved a heroic, larger-than-life value.

There are equally strong arguments (e.g., Thomas, 1988) and empirical evidence (e.g., Angle et al., 2006; Waldman et al., 2004) in favor of strong relationship between leadership style and organizational performance. Probably after reviewing arguments on both sides, it can be concluded that leader differences do account for performance variations but these impacts are generally not sufficient to outweigh the inbuilt differences among firms and differences created by contextual situations. Moreover, change in leadership could also be coincided with changes in other contextual situatons which have direct and greater impact on firm's performance. This paper indicated that there is no significant effect of leadership style of CEO on profitability of the organization, but it should not be interpreted as CEO having no role in profitability of the organization. This paper tried only to relate leadership style of CEO with profitability. However, CEO might bring many other attributes such as 
experience, technical know how, market knowledge, product development knowledge, and network to an organization.

\section{Implications and Future Research Directions}

The major practical implications of the findings of this paper would be for selecting CEOs and for designing their compensation plan. In Nepal, charisma of a person is considered as one of the many variables by Board of Directors of particularly newly established financial institutions while selecting CEO. This study clearly indicates that transformational leadership style (which is closely associated with charisma of a leader) has no relation with the financial measure of profitability. This gives a message to the Boards of Directors of financial institutions that charisma of the potential CEO or present CEO should not be associated with the financial performance of the institution, if the board wants to reward a CEO strictly on financial performance. This message is consistent with the empirical findings of research on CEO literature. Likewise, empirical evidence for the use of human capital as determinant of CEO compensation is not very strong (Gomez-Mejila, Tosi, \& Hinkin, 1987).

At a broader level, the study suggests that contextual variables have more crucial influence on a firm's profitibility measure than the CEO leadership style. It might also be that contextual variables are restricting the CEO leadership style to have an impact on the profitability measure. So, probably, the Board of Directors might also have to pay adequate attention to the contextual variables while selecting or awarding a CEO.

The total number of financial institutions participating in this study was 17 . This makes only 17 variations on the measures of financial profitability, total asset, and CEO tenure. Although total respondents in this study were 136, many respondents shared the same set of data on measures of financial profitability, total asset, and CEO tenure as there were many respondents from a single organization. Thus, this study can be further extended by incorporating more number of financial institutions to bring larger variation in data on measures of financial profitability, total asset, and CEO tenure. Employees working in offices of financial institutions outside Kathmandu, Bhaktapur and Lalitpur district were not included as population of the study because of time constraint. In the sample of this study, $9 \%$ were managers and $61 \%$ were at the supervisor or assistant level. It can be assumed that managerial level staff will be in better position to reflect on the leadership style of the CEO because they do interact more frequently with CEO compared to the employees of non-managerial level. Thus, this study can be further extended by increasing the level of managerial staff or by only taking managerial level staff as respondents.

Effect on the relationship between a CEO's leadership style and profitability of an organization because of differences in the national culture between the west and the east can be further explored. The study is limited to two leadership styles. However, there are also other types of leadership style in literature. It would be useful for academicians interested in organizational leadership if future research could expand this study by looking at a more complete range of leadership styles. Another delimitation of the study was that the respondents were from a single industry. Therefore, respondents from crosssection of industries will be helpful in generalizing the findings of this study. 


\section{References}

Allen, M. P., Panian, S. K., \& Lotz, R. E. (1979). Managerial succession and organizational performance: A recalcitrant problem revistied. Adminsitrative Science Quarterly, 24(2), 167180.http://dx.doi.org/10.2307/2392492

Angle, B., Nagarajan, J., Sonnenfeld, J., \& Srinivasan, D. (2006). Does CEO charisma matter? An empirical analysis of the relationships among organizational performance, environment uncertainity, and top management team: Perceptions of CEO charisma. Academy of Management Journal, 49(1), 161-174.http://dx.doi.org/10.5465/AMJ.2006.20785800

Barley, J. (1991). Firm resources and sustained competitive advantage. Journal of Management, 17(1), 99-120.http://dx.doi.org/10.1177/014920639101700108

Bass, B. (1985). Leadership and performance beyond expectations. New York, NY: Free Press.

Belias, D., \& Koustelios, A. (2014). Leadership and job satisfaction- A review. European Scientific Journal, 10(8).

Birnbaum, D., \& Somers, M. (1993). Fitting job performance into a turnover model: An examination of the form of the job performance-turnover relationship and path model. Journal of Management,

19(1), 1-11.http://dx.doi.org/10/1016/0149-2063(93)90041-K

Bogler, R. (2001). The influence of leadership style on teacher job satisfaction. Educational Administration Quartely, 37(5), 662-683.

Collins, J. (2001). Good to great. New York, NY: HarperCollins.

Day, D., \& Lord, R. (1988). Executive leadership and organizational performance. Journal of Management, 15(3), 453-464.http://dx.doi.org/10.1177/014920638801400308

eKantipur. (2013, January 31). Lessons in finance. Retrieved from:

http://www.ekantipur.com/2013/01/31/opinion/lessons-in-finance/366370.html

eKantipur. (2013, February 25). Banks rush to NRB for cash due to tight liquidity. Retrieved from http://www.ekantipur.com/2013/02/25/business/banks-rush-to-nrb-for-cash-due-to-tightliquidity/367574.html

Fields, D. L. (2002). Taking the measure of work. Thousand Oaks, CA: Sage.

Ghimire, S. (2014, April 4). Lack of monitoring ails cooperatives. Retrieved from http://www.myrepublica.com/portal/index.php?action=news_details\&news_id=72143

Gomez-Mejila, L., Tosi, H., \& Hinkin, T. (1987). Managerial control, performance, and executive compensation. Academy of Management Journal, 30(1), 51-70.http://dx.doi.org/10.2307/255895

Hogan, R., \& Kaiser, R. (2005). What we know about leadership. Review of General Psychology, 9(2), 169-180.http://dx.doi.org/10.1037/1089-2680.9.2.169

Joyce, W., Nohria, N., \& Roberson, B. (2003). What really works. New York, NY: HarperBusiness.

Lieberson, S., \& O'Conner, J. (1972). Leadership and organizational performance: A study of large corporations. American Sociological Review, 37(2), 117-130.

McFarlin, D., \& Rice, R. (1992). The role of facet importance as a moderator in job satisfaction processes. Journal of Organizational Behavior, 13(1), 41-54.

Meindl, J., \& Ehrlish, S. (1987). The romance of leadership and the evaluation of organizational performance. Academy of Management Journal, 30(1), 91-109. http://dx.doi.org/10.2307/255897

Mossholder, K., Bennett, N., \& Martin, C. (1998). A multilevel analysis of procedural justice context. Journal of Organizational Behavior, 19(2), 131-141. 
Pond, S., \& Geyer, P. (1991). Differences in the relation between job satisfaction and perceived work alternatives among older and younger blue-collar workers. Journal of Vocational Behavior,39(2), 251262.http://dx.doi.org/10.1016/0001-8791(91)90012-B

Poon, J. M. (2004). Effects of performance appraisal politics on job satisfaction and turnover intention. Personnel Review, 33(3), 322-334.http://dx.doi.org/10.1108/00483480410528850

Pfeffer, J. (1977). The ambiguity of leadership. Academy of Management Review, 2(1), 104-112.

The 1972-1973 quality of employment survey. Ann Arbor, MI: University of Michigan, Institute for Social Science.

Rad, A. M. M., \& Yarmohammadian, M. H. (2006). A study of relationship between manager's leadership style and employee's job satisfaction. Leadership in Health Serivces, 19(2), 11-28. http://dx.doi.org/10.1108/13660750610665008

Rice, R., Gentile, D., \& McFarlin, D. (1991). Facet importance and job satisfaction. Journal of Applied Psychology, 76(1), 31-39.http://dx.doi.org/10.1037/0021-9010.76.1.31

Saleem, H. (2015). The Impact of Leadership Styles on Job Satisfaction and Mediating Role of Perceived Organizational Politics. Procedia- Social and Behavioral Sciences, 563569.http://dx.doi.org/10.1016/j.sbspro.2015.01.403

Samuelson, B. A., Galbraith, C. S., \& McGuire, J. W. (1985). Organizational performance and top management turnover. Organization $\quad$ Studies, 275 291.http://dx.doi.org/10.1177/017084068500600304

Spotlight. (2011, June 1). Crisis in banks: Banking on unreal estate. Retrieved from http://www.spotlightnepal.com/News/Article/CRISIS-IN-BANKS-Banking-on-Un-Real-Estate

Thomas, A. B. (1988). Does leadership make a difference to organizational performance. Administrative Science Quarterly, 33(3), 388-400.http://dx.doi.org/10.2307/2392715

Tosi, H. (1982). Toward a paradigm shift in the study of leadership. In J. Hunt, U. Sekaran, \& C. Schriescheim (Eds.), Leadership: Beyond establishment views (pp. 222-233). Carbondale, IL: Southern Illininous University Press.

Tosi, H., Misangyi, V., Fanelli, A., Waldman, D., \& Yammarino, F. (2004). CEO charisma, compensation, and firm performance. Leadership Quartely,15(3), 405420.http://dx.doi.org/10.1016/j.leaqua.2004.02.010

Voon, M., Lo, M., Ngui, K., \& Ayob, N. (2011). The Influence of Leadership Styles on Employee's Job Satisfaction in Public Sector Organizations in Malaysia. International Journal of Bsiness, Management and Social Sciences, 2(1), 24-32.

Virany, B., Tushman, M., \& Romanelli, E. (1992). Executive succession and organizational outcomes in turbulent environments: An organizational learning approach. Organization Science, 3(1), 72 91. http://dx.doi.org/10.1287/orsc.3.1.72

Waldman, D. A., Ramirez, G. G., House, R. J., \& Puranam, P. (2001). Does leadership matter? CEO leadership attributes and profitability under condistions of perceived environment uncertainity. The Academy of Management Journal, 44(1), 134-143.http://dx.doi.org/10.2307/3069341

Waldman, D., Javidan, M., \& Varella, P. (2004). Charismatic leadership at the strategic level: A new application of upper echelons theory. Leadership Quartely, 15(3), 355380.http://dx.doi.org/10.1016/j.leaqua.2004.02.013

Williams, L., Gavin, M., \& Williams, M. (1996). Measurement and non-measurement process with negative affectivity and employee attitudes. Journal of Applied Psychology, 81(1), 88101. http://dx.doi.org/10.1037/0021-9010.81.1.88 
Zhu, W., Chew, I., \& Spangler, W. (2005). CEO transformationl leadership and organizational outcomes: The mediating role of human-capital-enhancing human resources management. TheLeadership Quartley, 16(1), 39-52.http://dx.doi.org/10.1016/j.leaqua.2004.06.001 


\section{Appendix: Survey Measures}

\section{Transactional and Transformational Leadership Style}

The respondents will be instructed as follows: "Think about the Chief Executive Officer of your company. To what extent does each of the following statement characterize the CEO of your company?" Transactional and Transformational leadership items will be provided in the mixed order.

Transactional Leadership

1. Takes actions if mistakes are made.

2. Points out what people will receive if they do what needs to be done.

3 . Reinforces the link between achieving goals and obtaining rewards.

4. Focuses attention on irregularities, exceptions, or deviations from what is expected.

5. Talks about special commendation and or promotion for good work.

Transformational Leadership

1. Instils pride in me for being associated with him/her.

OR

Goes beyond self-interest for the good of the group/organization.

2. Considers the moral and ethical consequences of decisions.

3. Talks optimistically about the future.

4. Examines critical assumptions to question whether they are appropriate.

5. Helps others to develop their strengths.

\section{Job Satisfaction}

1. If you had to decide all over again whether to take the job you now have, what would you decide?

2. How does this job compare with your ideal job (job you would most like to have)?

3. How does your job measures up to the sort of job you wanted when you took it?

4. All things considered, how satisfied are you with your current job?

5. In general, how much do you like your job? 